\title{
Dynamic Rapid Synthesis of Bis(2,2'-bipyridine)nitrato Zinc (II) Nitrate Using a Microwave Method and its Application to Dye-Sensitized Solar Cells (DSSC)
}

\author{
Youngmi Kim, Sujung Kim, Keepyung Nahm, and Misook Kang* \\ Department of Chemistry, College of Science, Yeungnam University, Gyeongsan, Gyeongbuk, 712-749, Korea \\ "E-mail:mskang@khu.ac.kr \\ Received April 27, 2010, Accepted August 30, 2010
}

\begin{abstract}
This study examined the synthesis of the crystal structure of bis(2,2'-bipyridine)nitrato zinc (II) nitrate, [Zn(bipy) 2 $\left.\left(\mathrm{NO}_{3}\right)\right]^{+} \mathrm{NO}_{3}^{-}$using a microwave treatment at $300 \mathrm{~W}$ and $60 \mathrm{~Hz}$ for the application to dye-sensitized solar cells. The simulated complex structure of the complex was optimized with the density functional theory calculations for the UV-vis spectrum of the ground state using Gaussian 03 at the B3LYP/LANL2DZ level. The structure of the acquired complex was expected a penta-coordination with four nitrogen atoms of bipyridine and the oxygen bond of the $\mathrm{NO}_{3}{ }^{-}$ ion. The reflectance UV-vis absorption spectra exhibited two absorptions (L-L transfers) that were assigned to the transfers from the ligand $(\sigma, \pi)$ of $\mathrm{NO}_{3}$ to the ligand $\left(\sigma^{*}, \pi^{*}\right)$ of pyridine at around $200-350 \mathrm{~nm}$, and from the non-bonding orbital (n) of $\mathrm{O}$ in $\mathrm{NO}_{3}$ to the p-orbital of pyridine at around $450-550 \mathrm{~nm}$, respectively. The photoelectric efficiency was approximately $0.397 \%$ in the dye-sensitized solar cells with the nanometer-sized $\mathrm{TiO}_{2}$ at an open-circuit voltage (Voc) of $0.39 \mathrm{~V}$, a short-circuit current density (Jsc) of $1.79 \mathrm{~mA} / \mathrm{cm}^{2}$, and an incident light intensity of $100 \mathrm{~mW} / \mathrm{cm}^{2}$.
\end{abstract}

Key Words: Bis(2,2'-bipyridine)nitrato zinc (II) nitrate, Microwave treatment, Dye-sensitized solar cells, Photoelectric efficiency

\section{Introduction}

Dye-sensitized solar cells (DSSC) have extensively been studied because of their attractive advantages, such as their low cost, less toxic manufacturing process, easy scale-up, light weight and potential use of flexible panels, compared to conventional p-n junction devices. ${ }^{1,2}$ An important element of DSSC materials is the dye compound, which consists of conjugated $\pi$-electrons and must exhibit the following four properties: 1$)$ Electrons must be generated from the HOME to the LUMO $(\delta \rightarrow$ $\pi$ electron transition) of the dye molecules through light absorption, and injected to the $\mathrm{LUMO}$ at $\mathrm{TiO}_{2}$ electrode. 2) All light in the visible area must be absorbed. 3) The chemical combination of the solid oxide $\left(\mathrm{TiO}_{2}\right)$ and the dye molecule must be strong. 4) The dye compound must be stable to light and heat. Particularly, the Ru complex is a typical example of a commercial dye that possesses all of the required properties for application in DSSCs. ${ }^{3-5}$ The high efficiency of the Ru complex arises because the electrons of both the singlet excited state and the excited triplet state can be injected into the conduction band of the semiconductor electrode $\left(\mathrm{TiO}_{2}\right)$. Especially, Nazeeruddin et al ${ }^{6}$ studied a high molar extinction coefficient charge transfer ruthenium sensitizer [Ru(4,-carboxylic acid-4'-carboxylate-2,2'bipyridine)(4,4'-di-(2-(3,6-dimethoxyphenyl)ethenyl)-2,2' bipyridine) $(\mathrm{NCS})_{2}$ ] that was anchored onto a nanocrystalline $\mathrm{TiO}_{2}$ films. This sensitizer achieved a very efficient sensitization in the visible region under AM 1.5 sunlight at a short-circuit photocurrent density of $18.84 \mathrm{~mA} / \mathrm{cm}^{2}$, an open-circuit voltage was $783 \mathrm{mV}$ and a fill factor of 0.73 , corresponding to an overall conversion efficiency of $10.82 \%$. On the other hand, Bignozzi et al. ${ }^{7}$ reported the preparation and photoelectrochemical characterization of a red sensitive osmium complex, containing 4,4,4-tricarboxy-2,2,6,2-terpyridine and cyanide ligands. The photochemical stability was qualitatively investigated and was better than the best Ru-based sensitizer to date, with a maximum monochromatic incident photon-to-current conversion efficiency (IPCE) of $85 \%$, a Jsc of $9.59 \mathrm{~mA} \mathrm{~cm}^{-2}$, a Voc of $0.552 \mathrm{~V}$, and a FF of 0.54 , corresponding to an overall conversion efficiency of $2.86 \%$ under AM 1.5 sunlight. Additionally, Chan et al. ${ }^{8}$ researched a series of sublimely substituted chlorotricarbonyl bis(phenylimino)acenaphthene rhenium(I) complexes that were used in the fabrication of photovoltaic devices. The best power conversion efficiency of these devices was $1.29 \%$ under an illumination of AM1.5 simulated solar light. In these examples, the dyes were composed of novel high-cost metals, such as Ru, Re, Ir and Os. In contrast, the use of low-cost dyes will hasten the commercial availability of DSSCs. Therefore, this study attempted to obtain stable transition metal complexes at a low cost and apply them to the dyes in DSSCs. Over the last few years, considerable efforts have been focused on the design and synthesis of zinc complexes, which have attracted extensive interest in many fields, such as blue or green emitting materials in LEDs (light emitting diodes). ${ }^{9-11}$ Particularly, Zhang et al. ${ }^{10}$ fabricated a $\mathrm{ZnO}$ LED by depositing undoped n-type $\mathrm{ZnO}$ onto a p-type layer. The turn-on voltage of this LED was about $3.70 \mathrm{~V}$ at $100 \mathrm{~K}$, which approached the band gap of $\mathrm{ZnO}$, and the electroluminescence spectra exhibited two bands at 423 and $523 \mathrm{~nm}$. On the other hand, Hong et al. ${ }^{11}$ showed that a device containing $20 \mathrm{wt} \%$ of a $\mathrm{ZnO}$ incorporated hybrid material ( $2 \mathrm{wt} \%)$ emitted nearly pure white light and a total luminous flux of $1.80 \mathrm{~lm}$ at an operating voltage of $20 \mathrm{~mA}$. The lifetime measurement data of the fabricated device containing the polymer-ZnO hybrid materials exhibited significant improvements over its pure counterpart because of the "caging effect" of the $\mathrm{ZnO}$ shell, which reduced the self-quenching of the polymer molecules in the core. 
Despite their great light-emitting ability, research has not focused on the use of $\mathrm{Zn}$-complexes in solar cases. Therefore, in this study, the zinc (II) complex was easily and stably synthesized through the formation of bipyridine chelate ligands on the metal center. A microwave thermal method at $300 \mathrm{~W}$ and $60 \mathrm{~Hz}$ was used the new synthesis approach. This method differed from the reflux method that was conducted under room temperature and atmosphere pressure. A perfect crystallization and a rapid synthesis time were expected from the microwave method. The crystal structure and the optical properties of the synthesized complex were analyzed using the X-ray photo, FT-IR, UV-vis, and photoluminescence spectra. Finally, this complex was examined for DSSC applications.

\section{Experimental}

Synthesis of bis(2,2'-bipyridine)nitrato zinc (II) nitrate. The $\mathrm{Zn}$ (II) complex was prepared using the microwave thermal method. As shown in Figure 1, $\mathrm{Zn}\left(\mathrm{NO}_{3}\right)_{2} \cdot 6 \mathrm{H}_{2} \mathrm{O}$ (Aldrich $\mathrm{Co}$, 99\%) and 2,2'-bipyridine (Wako Co, 99.0\%) were added to a round $500 \mathrm{~mL}$ flask at a molar ratio of approximately 1:3 with $120 \mathrm{~mL}$ of distilled water, and the mixture was stirred for $2 \mathrm{~h}$. The final solution was transferred into a microwave thermal reactor [Jung Hwa MQD; at Yeungnam University, 0 - 700 watt with water solvent, $60 \mathrm{~Hz}$ fixed] and treated at 300 watt and $60 \mathrm{~Hz}$ for 80 minutes. Microwave synthesis technology is the most effective design for applying microwave energy to a sample. It delivers true continuous power to the sample to ensure reproducible reaction conditions and results, regardless of volume, geometry, or changes in physical properties. The system is compact and easy-to-use, yet powerful enough to drive the most difficult reactions to completion in minutes. Faster reactions (10 - 1,000 times fasted) provide increased yields (10 $30 \%$ higher on average) and improved selectivity compared to the conventional thermal systems. Optimizing reactions in fewer steps gives more time to explore creativity. Microwave-enhanced chemistry has the added benefit of using much less solvent than traditional methods, resulting in significantly less waste and expense. A flowing coolant was applied to the top of the beaker in order to prevent the reaction mixture from

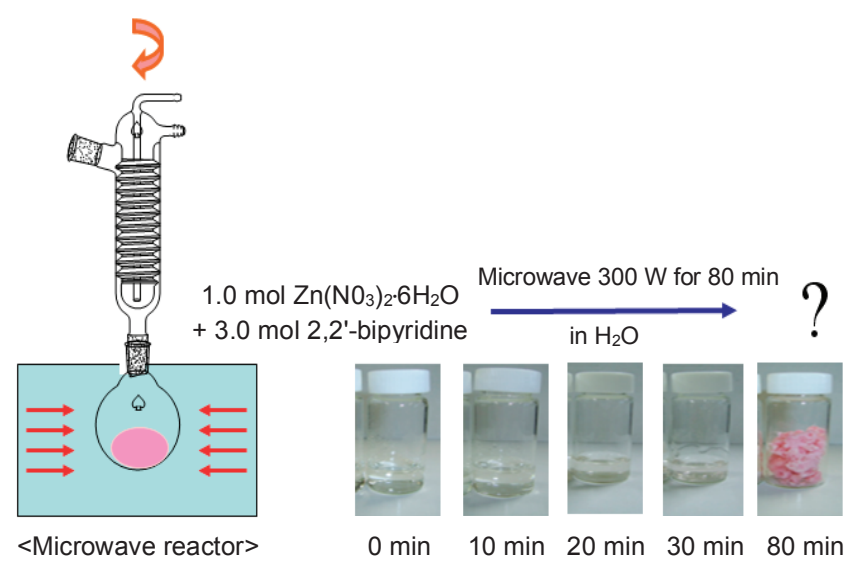

Figure 1. Preparation of bis(2,2'-bipyridine)nitrato zinc (II) nitrate using the microwave method. rapidly boiling. The solid zinc complex was separated from the solution after the reaction, and a pale pink $\mathrm{Zn}$ (II) complex was attained after drying at $353 \mathrm{~K}$.

Characterization. The ground state geometry of bis (2,2'-bipyridine)nitrato zinc (II) nitrate was assigned using a computational method and optimized using the Density functional theory (DFT) calculations with Gaussian $03^{12}$ at $298 \mathrm{~K}$ in the gas phase at the B3LYP/LANL2DZ level. The UV-vis spectrum of the ground state was obtained using the TDDFT at B3LYP/LANL2DZ. The X-ray photon spectroscopy (XPS) measurements of C1s, N1s, O1s, and Zn2p in bis(2,2'-bipyridine)nitrato zinc (II) nitrate were recorded using an AXISNOVA (Kratos Inc., at the Korea Basic Institute Jeonju center, South Korea) system that was equipped with a non-monochromatic AlKa $(1486.6 \mathrm{eV}) \mathrm{X}$-ray source. The powders were pelletized at $1.2 \times 10^{4} \mathrm{kPa}$ for $1 \mathrm{~min}$, and the $1.0-\mathrm{mm}$ pellets were stored overnight in a vacuum $\left(1.0 \times 10^{-7} \mathrm{~Pa}\right)$ in order to remove any water molecules from the surface prior to the measurements. The experiments were conducted using a $200-\mathrm{W}$ source power with an angular acceptance of $\pm 5^{\circ}$. The analyzer axis made a $90^{\circ}$ angle with the specimen surface. A Shirley function was used to remove the background in the XPS data analysis, and the signals were fitted using the mixed Lorentzian-Gaussian curves. The UV-vis spectra for bis(2,2'-bipyridine)nitrato zinc (II) nitrate were obtained using a Cary 500 spectrometer with a reflectance sphere over the spectral range from 200 to 800 nm. The FT-IR spectra (FT-IR-8100M, Shimazue Co., at Yeungnam University, South Korea) for bis(2,2'-bipyridine)nitrato zinc (II) nitrate were recorded on a Mattson 1000 spectrometer using the diffused reflectance method. The powdered sample was mixed with $\mathrm{CaF}_{2}$ and pressed into pellet form. The scan range for the measurements ranged from 400 to $3600 \mathrm{~cm}^{-1}$, and 50 scans were accumulated to obtain a resolution of $4.0 \mathrm{~cm}^{-1}$. Bis(2,2'-bipyridine)nitrato zinc (II) nitrate underwent fluorescence (FL) spectroscopy (Model FP-777, Jasco, at Yeungnam University, South Korea) in order to examine the number of photo-excited electron hole pairs. The target wavelength was $325 \mathrm{~nm}$, and $0.5 \mathrm{mM} \mathrm{Zn}$-complex was diluted in acetonitrile. The cyclic voltammetry data were obtained using a BAS 100B at room temperature and a scan rate of $100 \mathrm{mV} / \mathrm{s}$ with $0.1 \mathrm{M}$ $\mathrm{KCl}$ (0.2 $\mathrm{mM} \mathrm{Zn}$-complex) as the supporting electrolyte a platinum wire as the working and counter electrodes, and $\mathrm{Ag} / \mathrm{AgCl}$ as the reference electrode. Ferrocene was used as the internal reference, and the observed potentials of the redox couples were referenced to ferrocene.

Manufacturing dye-sensitized solar cells (DSSC). A slurry was produced by mixing $5.0 \mathrm{~g}$ nanometer-sized $\mathrm{TiO}_{2}$ powder with $10 \mathrm{~mL}$ alcohol after sonication for $24 \mathrm{~h}$ at $1200 \mathrm{~W} / \mathrm{cm}^{2}$ in order to prepare the $\mathrm{TiO}_{2}$ thin film (Degusa P-25, 50 - $70 \mathrm{~nm}$ ). $\mathrm{TiO}_{2}$ was coated onto a fluorine-doped, $\mathrm{SnO}_{2}$ conducting glass plate (Hartford FTO, $\sim 30 \mathrm{ohm} / \mathrm{cm}^{2}, 80 \%$ transmittance in the visible region) twice using the squeeze printing technique in order to fabricated the thin film with an approximate thickness of $10.0 \mu \mathrm{m}$. The film was heat treated at $723 \mathrm{~K}$ for 30 minutes in order to remove the alcoholic solvent. The $\mathrm{P}-25 \mathrm{TiO}_{2}$ thin film electrode was immersed in a $3.0 \times 10^{-4} \mathrm{M}$ bis(2,2'-bipyridine)nitrato zinc (II) nitrate dye solution at room temperature for $24 \mathrm{~h}$, rinsed with anhydrous ethanol and dried. The Pt-coated 
FTO electrode was placed over the dye-adsorbed $\mathrm{TiO}_{2}$ electrode, and the edges of the cell were sealed with a sealing sheet (PECHM-1, Mitsui-Dupont Poly Chemical). The redox electrolyte consisted of $0.50 \mathrm{~mol} \mathrm{KI}, 0.05 \mathrm{~mol} \mathrm{I}_{2}$, and $0.5 \mathrm{~mol} \mathrm{4-tert-}$ butylpyridine as the solvent. The photocurrent-voltage (I-V) curves were used to calculate the Jsc, Voc, FF, and overall conversion efficiency of the DSSC. The I-V curves were measured under white light irradiation from a xenon lamp (max. $150 \mathrm{~W}$, Newport), with an incident light intensity and an active cell area of $100 \mathrm{~mW} / \mathrm{cm}^{2}$ and $0.40(0.8 \times 0.5) \mathrm{cm}^{2}$, respectively.

\section{Results and Discussion}

Characterization of bis(2,2'-bipyridine)nitrato zinc (II) nitrate. Unfortunately, the synthesized compound could not be re-crystallized in this study. Therefore, the structure was attained using a computational method and optimized using the Density Functional Theory (DFT) calculations, with Gaussian 03 at the B3LYP/LANL2DZ level. The UV-vis spectrum of the ground state was obtained using the TDDFT at B3LYP/LANL2DZ. First, the synthesized complex was assumed to have a hexa- or penta-coordination, and then the theoretical UV-vis spectrum was simulated using TDDFT. The spectrum in Figure 2A confirmed that that the structure was penta-coordinated, which matched the actual analyzed UV-vis spectrum in Figure 2B. In Figure 2A, the two special absorptions at 429 and $441 \mathrm{~nm}$ were assigned to the transfers from the non-bonding ligand (n, $\mathrm{HOMO}$ ) of $\mathrm{NO}_{3}$ to the $\mathrm{p}^{*}$ ligands (LUMO) of pyridine in pentacoordinated structure. However, the spectrum did not correspond to a hexa-coordination, having the four bipyridine $\mathrm{N}$ atoms and chelated $\mathrm{NO}_{3}$. The signal refinement and the selected spectra for the penta-coordinated complex, bis(2,2'-bipyridine)nitrato zinc (II) nitrate, are given in Appendix 1. According to the simulation in Figure 2A, the $\mathrm{Zn}$ atom of the title complex (II) had a distorted octahedral coordination and was linked by the four bipyridine $\mathrm{N}$ atoms. One of the $\mathrm{O}$-atom donors lied further from the $\mathrm{Zn}$ atom because of the pseudo Jahn-Teller distortions, without chelated $\mathrm{NO}_{3}$. The $\mathrm{Zn}$ atom exhibited a stereochemistry with a pseudo- $\mathrm{C}_{2}$ symmetry (perfectly hexa-coordination) bisecting the $\mathrm{NO}_{3}$ ligand and passing between the bipyridine ligands. The computational results confirmed that the geometry of the $\left.[\mathrm{Zn} \text { (bipy) })_{2}\left(\mathrm{NO}_{3}\right)\right]^{+}$complex was a penta-coordination with the $\mathrm{NO}_{3}$-ligated structure. On the other hand, Figure $2 \mathrm{~B}$ shows the actual reflectance UV-vis absorption spectrum in the wavelength range from $200-800 \mathrm{~nm}$ for the $\left[\mathrm{Zn}(\text { bipy })_{2}\left(\mathrm{NO}_{3}\right)\right]^{+}$ species. Two types of absorption band, which were assigned to $\mathrm{L}-\mathrm{L}\left[\mathrm{p}[\sigma, \pi]\left(\mathrm{NO}_{3}\right) \rightarrow \mathrm{p}^{*}\left[\sigma^{*}, \pi^{*}\right]\left(\mathrm{NO}_{3}\right)\right.$ or $\left.\mathrm{p}(\mathrm{bpy}) \rightarrow \mathrm{p}^{*}(\mathrm{bpy})\right]$ transitions were localized at 230,265 , and $320 \mathrm{~nm}$ in both the bipyridine compound and the synthesized $\left[\mathrm{Zn}(\text { bipy })_{2}\left(\mathrm{NO}_{3}\right)\right]^{+}$ complex. Otherwise, the main spectrum of the colored complexes, which was assigned to $\mathrm{Zn} \rightarrow \mathrm{Zn}$ d-d transfer transitions, was not observed because $\mathrm{Zn}$ (II) had a full filled d-orbital. Similar to the theoretical spectrum in Figure 2A, the two absorption bands, which were assigned to the transfers from the nonbonding ligand ( $\mathrm{n}, \mathrm{HOMO}$ ) of $\mathrm{NO}_{3}$ to the $\mathrm{p}^{*}$ ligands (LUMO) of pyridine at around $450 \sim 550 \mathrm{~nm}$, were also absorbed in the penta-coordinated structure, $\left[\mathrm{Zn}(\text { bipy })_{2}\left(\mathrm{NO}_{3}\right)\right]^{+}$complex.

Figure 3 presents the typical survey and high-resolution
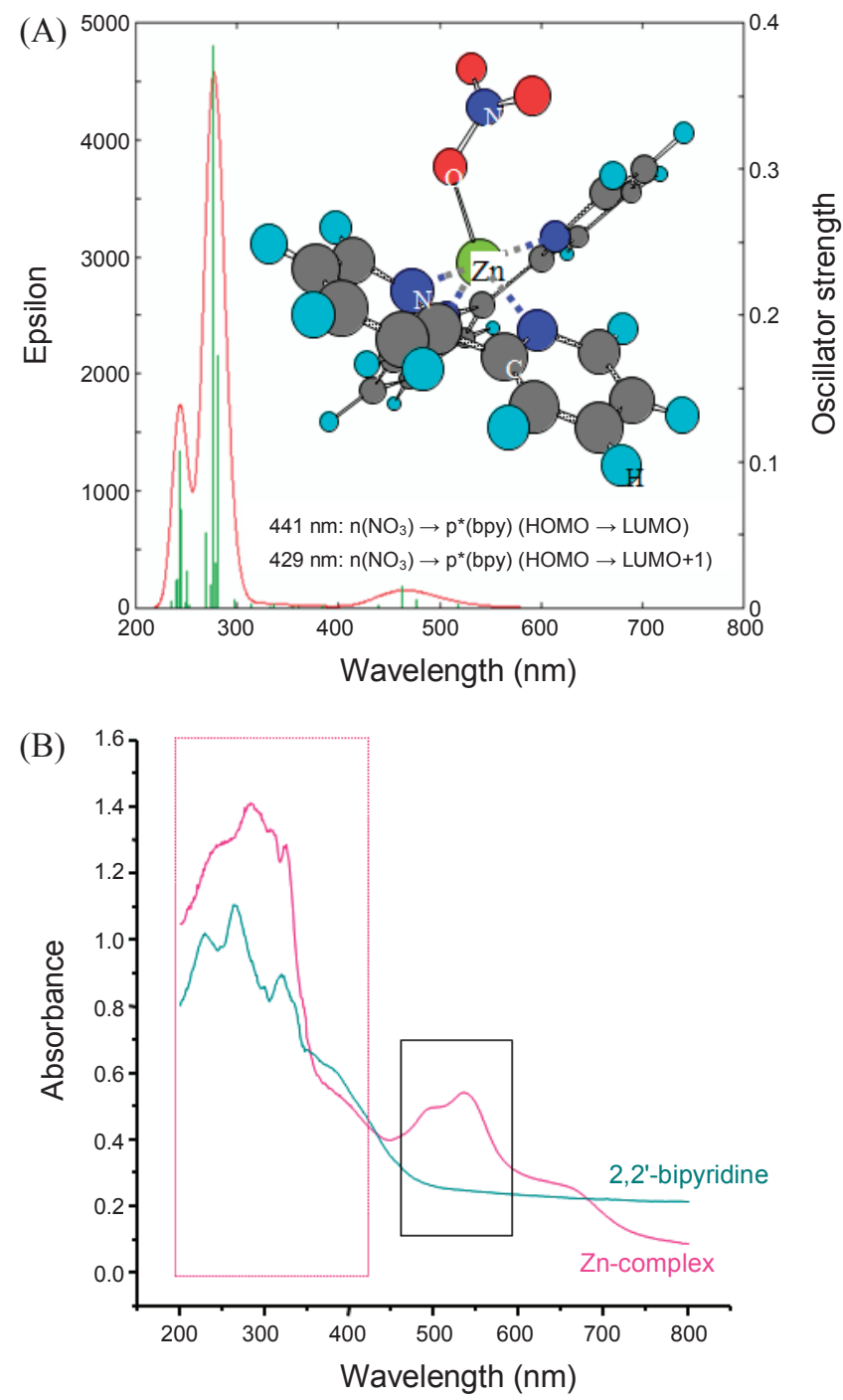

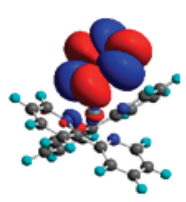

(1) $\mathrm{HOMO}$

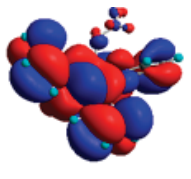

(2) LUMO

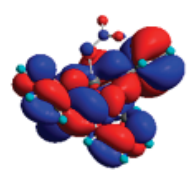

(2) $\mathrm{LUMO}+1$
Figure 2. The expected structure (inside) of bis(2,2'-bipyridine)nitrato zinc (II) nitrate, and the (A) theoretical and (B) actual reflectance UV-vis absorption spectra of bis(2,2'-bipyridine)nitrato zinc (II) nitrate.

spectra from the quantitative XPS analysis of the [ $\mathrm{Zn}(\text { bipy })_{2}$ $\left.\left(\mathrm{NO}_{3}\right)\right]^{+}$complex. The survey spectra contained the $\mathrm{C} 1 \mathrm{~s}, \mathrm{~N} 1 \mathrm{~s}$, $\mathrm{O}_{1 \mathrm{~s}}$ and $\mathrm{Zn} 2 \mathrm{p}$ peaks. The $2 \mathrm{p}_{3 / 2}$ and $2 \mathrm{p}_{1 / 2}$ spin-orbital photoelectrons of the $\mathrm{Zn}$-centered metal that were located at binding energy of 1022 - 1023 and $1045-1047 \mathrm{eV}$, respectively, were assigned to the $\mathrm{Zn}^{2+}$ component. ${ }^{13}$ The $\mathrm{O} 1 \mathrm{~s}$ spin-orbital photoelectron of $\mathrm{NO}_{3}$ was located at binding energy of $532-533 \mathrm{eV}$, and, N1s peak at $399.8 \mathrm{eV}$ was assigned to cyanide in bipyridine. Finally, the $\mathrm{C} 1 \mathrm{~s}$ spin-orbital photoelectron was located at a binding energy of $285 \mathrm{eV}$ and was assigned to the carbide in bipyridine. These results implied that the $\left[\mathrm{Zn}(\text { bipy })_{2}\left(\mathrm{NO}_{3}\right)\right]^{+}$ complex was perfectly synthesized in this study. 


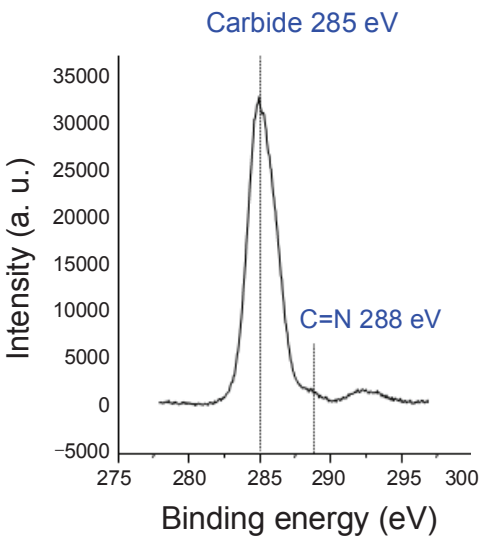

(a) $\mathrm{C} 1 \mathrm{~s}$

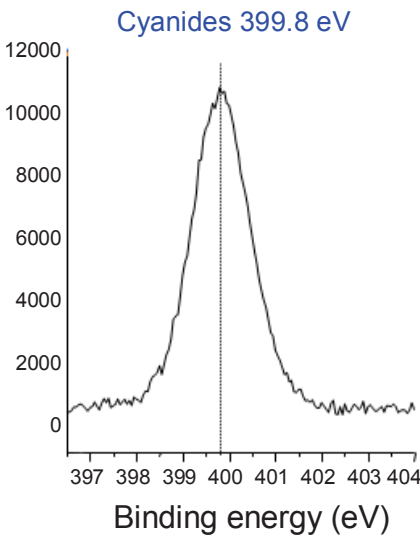

(b) N1s

Figure 3. XPS curves of bis(2,2'-bipyridine)nitrato zinc (II) nitrate.

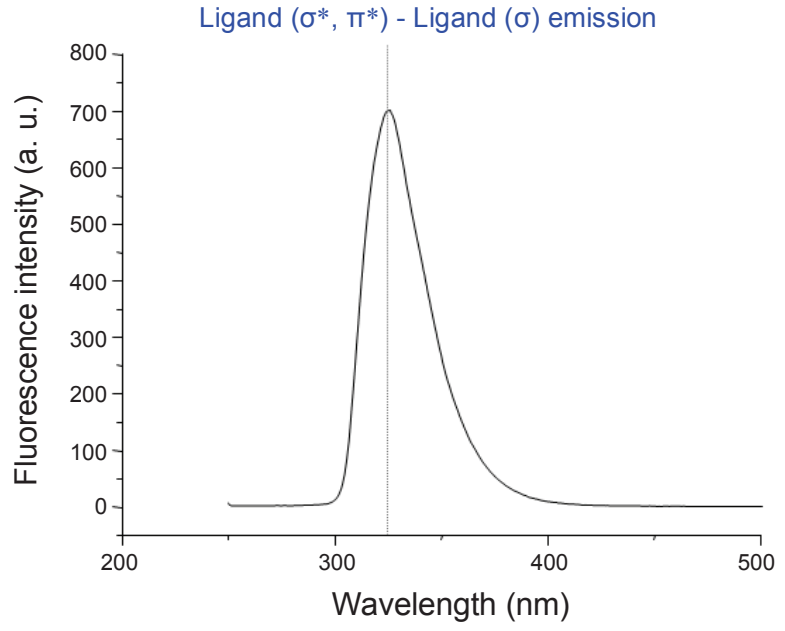

Figure 4. FL spectrum of bis(2,2'-bipyridine)nitratocopper (II) nitrate.

The FL curve suggested that the electrons in the HOMO of bis(2,2'-bipyridine)nitrato zinc (II) nitrate were transferred to the LUMO, and then the excited electrons were stabilized through photoemission, in Figure 4. In general, the FL intensity increases with increasing number of emitted electrons, resulting from the recombination between the excited electrons and holes, and, consequently, a decrease in the photo activity. Therefore, there is a strong relationship between the FL intensity and the photo activity. In particular, the FL intensity greatly decreases when a metal captures excited electrons or exhibits conductivity, which is known as the relaxation process. Only one curve in the $\left[\mathrm{Zn}(\text { bipy })_{2}\left(\mathrm{NO}_{3}\right)\right]^{+}$complex exhibited a yellow/green emission at $325 \mathrm{~nm}$. The band broadening was attributed to the overlapped emissions from the higher and lower excited states to the ground states, corresponding to the ligand-to-ligand transitions because of the effects on the emission energy from the free ligand to the complex. ${ }^{14}$ The HOMO of the complex was a non-bonding orbital, which was localized on the non-coordinating oxygen atom, or otherwise, the HOMO was the carbon atom in the bipyridyl ring. Generally, the energy of the HOMO level of the complex is much lower than the free ligand. The LUMO of the complex was a p-orbital, consisting mostly of

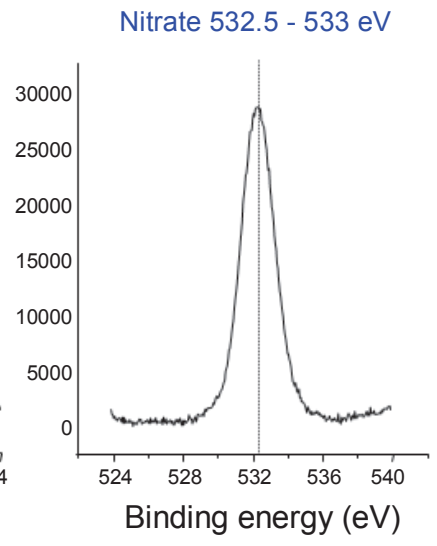

(c) $01 \mathrm{~s}$

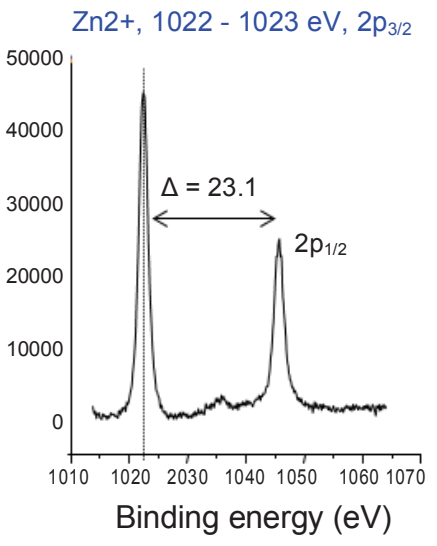

(d) $Z n 2 p$ atomic orbits from one of the bipyridyl rings. The role of the metal ion was to increase the co-planarity and the conformational rigidity in the molecule structure and decrease the $n \rightarrow p$ energy gap.

The oxidation potentials were measured using cyclic voltammetry in distilled water solutions of the $0.2 \mathrm{mM}$ complex with glassy carbon as the working electrode and $0.1 \mathrm{M} \mathrm{KCl}$ as the supporting electrolyte, in Figure 5. The $\mathrm{Zn}(0) \rightarrow \mathrm{Zn}(\mathrm{II})$ redox process was reversible. The voltages of the HOMO and LUMO in $\left[\mathrm{Zn}(\text { bipy })_{2}\left(\mathrm{NO}_{3}\right)\right]^{+}$were -4.11 and $-1.63 \mathrm{eV}$, respectively. Therefore, the expected band gap was $2.48 \mathrm{eV}$. Additionally, the progressive shift in $\left[\mathrm{Zn}(\text { bipy })_{2}\left(\mathrm{NO}_{3}\right)\right]^{+}$at lower potential values upon the deprotonation of the $\mathrm{NO}_{3}$ groups was in agreement with the destabilization effects of the negative $\mathrm{NO}_{3}$ charge on the bipy p-orbital. Therefore, the back-donation from the metal was not as effectively accepted. The electron transfer diagram was proposed in Figure 5 based on these results. When a dye molecule absorbs light, the electrons of the highest occupied molecular orbital (HOMO) orbital are excited to an electronically excited state, corresponding to the lowest unoccupied molecular orbital (LUMO) orbital. The excited dye molecule injected an electron into the conducting band of the $\mathrm{TiO}_{2}$ film, The oxidized dye was restored by an electron donation from the reducing ions in the electrolyte, which is usually an organic solvent containing a redox system. The donated electron was in turn regenerated through the reduction of the conjugated ions in the electrolytes. The circuit was completed by the electron migration through an external load. ${ }^{15-17}$ The location of the dye LUMO energy position must be higher than the LUMO energy position of $\mathrm{TiO}_{2}$. Fortunately, in this study, the LUMO of the synthesized $\left[\mathrm{Zn}(\text { bipy })_{2}\left(\mathrm{NO}_{3}\right)\right]^{+}$complex was located at a higher position than $\mathrm{TiO}_{2}$, resulting in a successful photovoltaic cycle.

Figure 6 shows the interfacial binding energy between the dye molecule, $\left.[\mathrm{Zn} \text { (bipy) })_{2}\left(\mathrm{NO}_{3}\right)\right]^{+}$complex and the surface of the modified $\mathrm{TiO}_{2}$, which was examined using FT-IR spectroscopy. Generally, the efficiency of the charge injection process is strongly dependent on the bonding structure of the dye molecules that are adsorbed on the $\mathrm{TiO}_{2}$ film. Additionally, the electron transfer in a DSSC is strongly affected by the electrostatic 

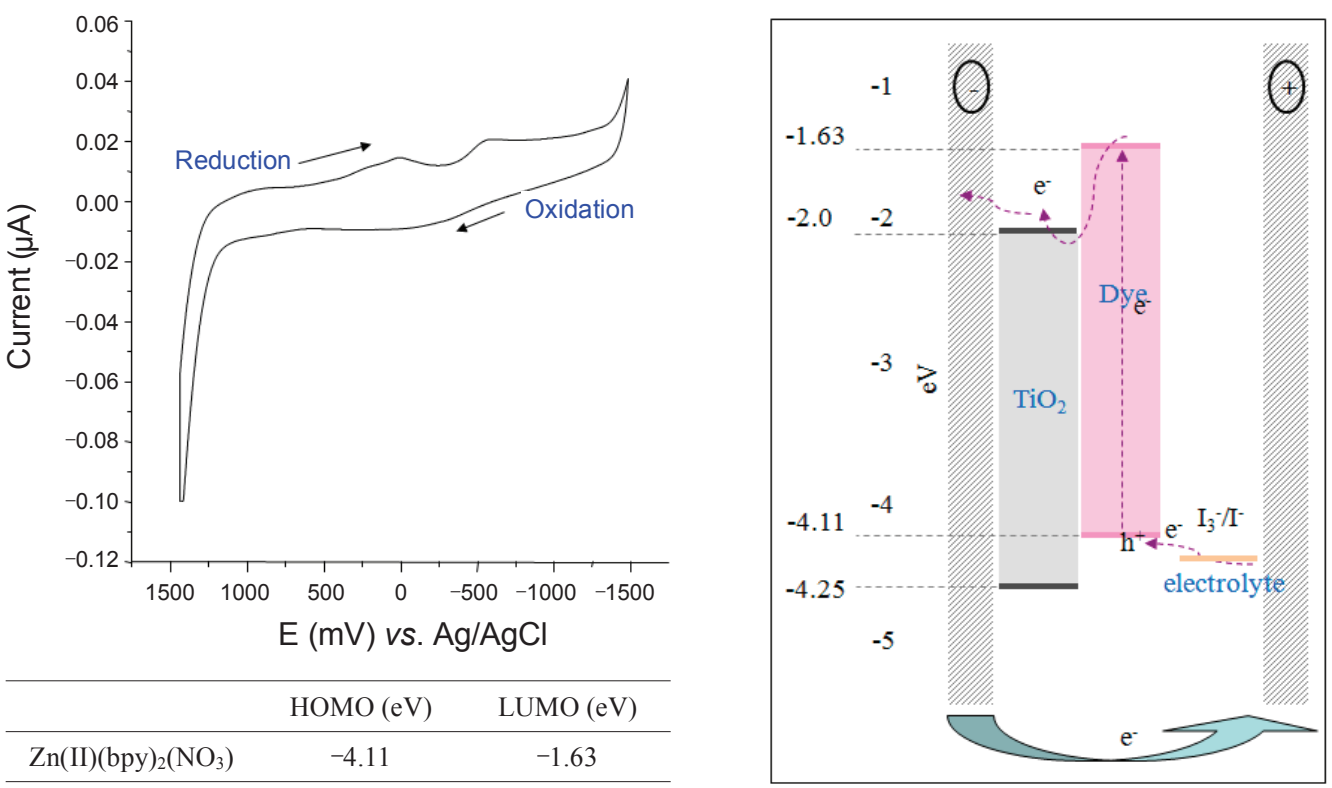

Figure 5. Expected electron transfer diagram of the DSSC with bis (2,2'-bipyridine)nitrato zinc (II) nitrate, and the cyclic voltammetry of bis (2,2'-bipyridine)nitrato zinc (II) nitrate in distilled water solutions of the $0.2 \mathrm{mM}$ complex using a glassy carbon as the working electrode and $0.1 \mathrm{M} \mathrm{KCl}$ as the supporting electrolyte.

Asym. $\mathrm{N}=\mathrm{O} 1550 \quad$ Sym. $\mathrm{N}=\mathrm{O} 1350$

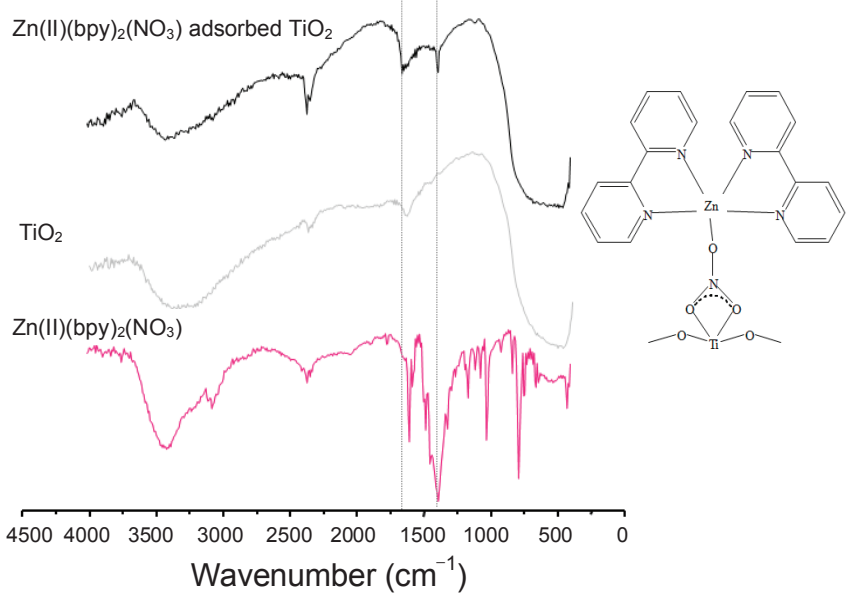

Figure 6. FT-IR spectroscopy of bis(2,2'-bipyridine)nitrato zinc (II) nitrate and an adsorbed model between the surface of $\mathrm{TiO}_{2}$ and the $\mathrm{Zn}(\mathrm{II})$ complex.

and chemical interactions between the $\mathrm{TiO}_{2}$ surface and the adsorbed dye molecules. Regarding the specific adsorption for FT-IR, ${ }^{18}$ the IR spectra exhibited absorptions at $1600-1500$ and $1390-1300 \mathrm{~cm}^{-1}$, which were assigned to the $\mathrm{C}=\mathrm{C}$ and $\mathrm{N}=\mathrm{O}$ $\left(-\mathrm{NO}_{2}\right)$ stretching modes, respectively. After the dye-adsorption, the $\mathrm{N}=\mathrm{O}$ band decreased because it was transferred to the $\mathrm{N}-\mathrm{O}$ stretching mode because of the bidentate coordination of the $\left.[\mathrm{Zn} \text { (bipy) })_{2}\left(\mathrm{NO}_{3}\right)\right]^{+}$dye on the surface of the $\mathrm{TiO}_{2}$ films. The bond between $\mathrm{NOO}^{-}$and the surface of the $\mathrm{TiO}_{2}$ film was assumed to be strong because of the perfect bidentate linkage. Furthermore, the IR spectrum of the dye- $\mathrm{TiO}_{2}$ exhibited a broad band at around $500 \mathrm{~cm}^{-1}$, which was assigned to metal-O, corresponding to the new Ti-O bond between the $\mathrm{O}^{-} \mathrm{NOO}^{-}$and

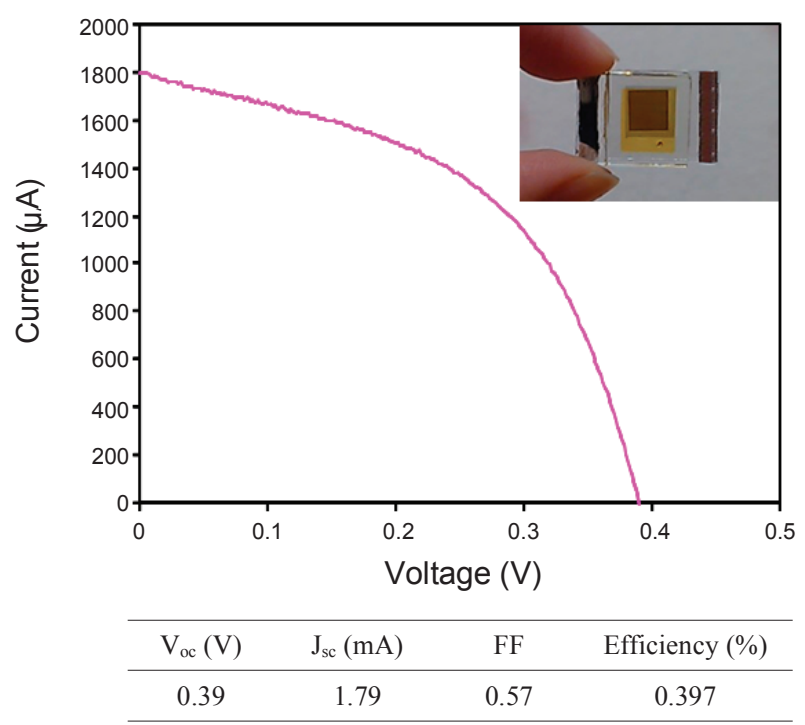

Figure 7. Photocurrent-voltage (I-V) curves of $\mathrm{TiO}_{2}$ that was adsorbed with bis(2,2'-bipyridine)nitrato zinc (II) nitrate.

the Ti atom. Therefore, the adsorbed model between the surface of $\mathrm{TiO}_{2}$ and the $\left[\mathrm{Zn}(\text { bipy })_{2}\left(\mathrm{NO}_{3}\right)\right]^{+}$dye was proposed on the right in Figure 6.

Energy conversion efficiency on DSSC. The photoelectric properties were measured using a voltmeter and ampere meter (Model 2000, Keithley) with a variable load. A 150 W illuminant Xenon lamp was employed as the radiation source at an AM-1.5 radiation angle. The light intensities were measured using a power analyzer and a thermal smart-sensor. The FF and the solar energy conversion efficiency ( $\eta$ ) were calculated using Equations (1) and (2), respectively. ${ }^{19,20}$

$$
\mathrm{FF}=I_{\max } \times V_{\max } / I_{\mathrm{sc}} \times V_{\mathrm{oc}}
$$




$$
\begin{aligned}
\eta(\%) & =P_{\text {out }} / P_{\text {in }} \times 100=I_{\text {max }} \times V_{\text {max }} / P_{\text {in }} \times 100 \\
& =I_{\text {sc }} \times V_{\text {oc }} \times F F
\end{aligned}
$$

Figure 7 shows the $\mathrm{I}-\mathrm{V}$ curves of $\mathrm{TiO}_{2}$ that was adsorbed with the $\left[\mathrm{Zn}(\text { bipy })_{2}\left(\mathrm{NO}_{3}\right)\right]^{+}$complex. The $\mathrm{FF}, \mathrm{V}_{\mathrm{oc}}, \mathrm{J}_{\mathrm{sc}}$, and overall energy efficiency were determined using the above equations. The $\left.\mathrm{TiO}_{2} /[\mathrm{Zn} \text { (bipy) })_{2}\left(\mathrm{NO}_{3}\right)\right]^{+}$DSSC had a Voc of $0.39 \mathrm{~V}$ and a Jsc of $1.79 \mathrm{~mA} / \mathrm{cm}^{2}$ at an incident light intensity of 100 $\mathrm{mW} / \mathrm{cm}^{2}$. The power conversion efficiency of the $\mathrm{TiO}_{2} /[\mathrm{Zn}$ (bipy) $\left.)_{2}\left(\mathrm{NO}_{3}\right)\right]^{+}$DSSC was $0.397 \%$. Unexpectedly, the prepared $\left[\mathrm{Zn}(\text { bipy })_{2}\left(\mathrm{NO}_{3}\right)\right]^{+}$dye was well-adsorbed on the $\mathrm{Ti}$ in the $\mathrm{TiO}_{2}$ film, despite the absence of the $\mathrm{COO}^{-}$group in the bipyridine ring, because of the attachment of two $\mathrm{O}$ atoms in $\mathrm{NO}_{3}$ to the Ti metal. The efficiency was smaller than the efficiency of the Ru-complex (about 3.0 - 5.0\%, N719), which is a commonly dye in DSSCs. The efficiency resembled the photovoltaic efficiency on DSSCs that were assembled using Fe-complex dyes. ${ }^{21}$ However, the photovoltaic efficiency could potentially be greatly enhanced in future research through the modification of the bipyridine group with electron donating or withdrawing ligands so that it stably combines with the transition metals.

\section{Conclusions}

The microwave method, is a simple and dynamic rapid synthetic procedure that was used to prepare the $\left[\mathrm{Zn}(\text { bipy })_{2}\left(\mathrm{NO}_{3}\right)\right]^{+}$ complex with a partially visible absorption region, via a perfectly reversible electrochemical process. The density functional theory calculations revealed that the acquired complex was supposed to a penta-coordination with four nitrogen atoms of bipyridine and the oxygen bond of the $\mathrm{NO}_{3}{ }^{-}$ion. The FL spectra of the complex displayed a yellow/green luminescence in the acetonitrile solvent. The reflectance UV-vis absorption spectra for the complex exhibited three absorptions that were assigned to two types of L-L transfers at around $200-350 \mathrm{~nm}$ and $450-550 \mathrm{~nm}$. The IR spectra suggested that two $\mathrm{O}$ atoms of $\mathrm{NO}_{3}$ - were bonded to the surface of $\mathrm{TiO}_{2}$. The photoelectric efficiency was approximately $0.397 \%$ in the DSSC with the nanometer-sized $\mathrm{TiO}_{2}$ at a Voc of $0.39 \mathrm{~V}$, a Jsc of $1.79 \mathrm{~mA} /$ $\mathrm{cm}^{2}$, and a fill factor of 0.57 .

Acknowledgments. This research was supported by the Basic Science Program through the National Research Foundation of Korea (NRF) funded by the Ministry of Education, Science and Technology (2009-0064865). The authors are very grateful for this support.

\section{References}

1. Chou, C. S.; Yang, R. Y.; Yeh, C. K.; Lin, Y. J. Powder Technol. 2009, 194, 95 .
2. An, H.; Xue, B.; Li, D.; Li, H.; Meng, Q.; Guo, L.; Chen, L. Electrochem. Commun. 2006, 8, 170.

3. Song, H. K.; Park, Y. H.; Han, C. H.; Jee, J. G. J. Ind. Eng. Chem. 2009, 15, 62 .

4. Li, X.; Gui, J.; Yang, H.; Wu, W.; Li, F.; Tian, H.; Huang, C. Inorg. Chim. Acta 2008, 361, 2835.

5. Christiana, A. M.; Irene, V.; Athanassios, I. P.; Polycarpos, F. J. Photochem. Photobiol. A 2007, 191, 6.

6. Nazeeruddin, Md. K.; Bessho, T.; Cevey, Le.; Ito, S.; Klein, C.; De Angelis, F.; Fantacci, S.; Comte, P.; Liska, P.; Imai, H.; Graetzel, M. J. Photochem. Photobiol. A 2007, 185, 331.

7. Argazzi, R.; Larramona, G.; Contado, C.; Bignozzi, C. A. J. Photochem. Photobiol. A 2004, 164, 15.

8. Mak, C. S. K.; Wong, H. L.; Leung, Q. Y.; Tam, W. Y.; Chan, W. K.; Djurišić, A. B. J. Organomet. Chem. 2009, 694, 2770.

9. Kalisch, H.; Hamadeh, H.; RuK land, R.; Krysa, J.; Berntgen, A.; Heuken, M. J. Cryst. Growth 2000, 214/215, 1163.

10. Zhanga, Z. Z.; Wei, Z. P.; Lu, Y. M.; Shen, D. Z.; Yao, B.; Li, B. H.; Zhao, D. X.; Zhang, J. Y.; Fan, X. W.; Tang, Z. K. J. Cryst. Growth 2007, 301-302, 362.

11. Uthirakumar, P.; Lee, Y. S.; Suh, E. K.; Hong, C. H. J. Lumin. 2008, $128,287$.

12. GAUSSIAN03, Frisch, M. J.; Trucks, G. W.; Schlegel, H. B.; Scuseria, G. E.; Robb, M. A.; Cheeseman, J. R.; Montgomery, J. A., Jr.; Vreven, T.; Kudin, K. N.; Burant, J. C.; Millam, J. M.; Iyengar, S. S.; Tomasi, J.; Barone, V.; Mennucci, B.; Cossi, M.; Scalmani, G.; Rega, N.; Petersson, G. A.; Nakatsuji, H.; Hada, M.; Ehara, M.; Toyota, K.; Fukuda, R.; Hasegawa, J.; Ishida, M.; Nakajima, T.; Honda, Y.; Kitao, O.; Nakai, H.; Klene, M.; Li, X.; Knox, J. E.; Hratchian, H. P.; Cross, J. B.; Bakken, V.; Adamo, C.; Jaramillo, J.; Gomperts, R.; Stratmann, R. E.; Yazyev, O.; Austin, A. J.; Cammi, R.; Pomelli, C.; Ochterski, J. W.; Ayala, P. Y.; Morokuma, K.; Voth, G. A.; Salvador, P.; Dannenberg, J. J.; Zakrzewski, V. G.; Dapprich, S.; Daniels, A. D.; Strain, M. C.; Farkas, O.; Malick, D. K.; Rabuck, A. D.; Raghavachari, K.; Foresman, J. B.; Ortiz, J. V.; Cui, Q.; Baboul, A. G.; Clifford, S.; Cioslowski, J.; Stefanov, B. B.; Liu, G.; Liashenko, A.; Piskorz, P.; Komaromi, I.; Martin, R. L.; Fox, D. J.; Keith, T.; Al-Laham, M. A.; Peng, C. Y.; Nanayakkara, A.; Challacombe, M.; Gill, P. M. W.; Johnson, B.; Chen, W.; Wong, M. W.; Gonzalez, C.; Pople, J. A. Gaussian 03; Revision C.02; Gaussian Inc.: Wallingford, CT, 2004.

13. Mouider, J. F.; Stickle, W. F.; Sobol, P. E.; Bomben, K. D. Handbook of X-ray Photoelectron Spectroscopy; Chastain, J., Ed.; Perkin-Elmer Corporation: 1992.

14. Huang, L.; Zhong, A. G.; Chen, D. B.; Liang, H. D. J. Mol. Struct. 2009, $922,135$.

15. Gagliardi, S.; Giorgi, L.; Giorgi, R.; Lisi, N.; Dikonimos, M. T.; Salernitano, E.; Rufoloni, A. Superlattices Microst. 2009, 46, 2058.

16. Philipp, W.; Markus, Z.; Christian, S.; Marko, B.; Uřsa, O. K.; Dirk, G.; Peter, W.; Andreas, H.; Heiner, J. G. J. Photochem. Photobiol. A 2008, 197, 25.

17. Lee, W.; Ramasamy, E.; Lee, D.; Song, J. Sol. Energ. Mat. Sol. C 2008, 92,814 .

18. AkyuĖza, S.; AkyuĖz, T.; Ozer, N. M. J. Mol. Struct. 2001, 565$566,493$.

19. Aziz, M. S. Solid State Electron. 2008, 52, 1145.

20. El-Nahass, M. M.; Zeyada, H. M.; Abd-El-Rahmana, K. F.; Darwish, A. A. A. Sol. Energ. Mat. Sol. C 2007, 91, 1120.

21. Jayaweera, P. M.; Palayangoda, S. S.; Tennakone, K. J. Photochem. Photobiol. A 2001, 140, 173. 